\title{
Successful lung transplantation in an HIV seropositive patient with desquamative interstitial pneumonia: a case report
}

Shaun Ong ${ }^{1}$, Robert D Levy ${ }^{2,3}$, John Yee ${ }^{4}$, Nilu Partovi ${ }^{5}$, Andrew Churg ${ }^{6,7,8}$, Philippe Roméo ${ }^{9}$, Jean Chalaoui ${ }^{10}$, Roland Nador ${ }^{2,3}$, Alissa Wright ${ }^{11}$, Hélène Manganas ${ }^{12}$ and Christopher J Ryerson ${ }^{2,8^{*}}$ (D)

\begin{abstract}
Background: Until recently, lung transplantation was not considered in patients with human immunodeficiency virus (HIV). HIV seropositive patients with suppressed viral loads can now expect long-term survival with the advent of highly active antiretroviral therapies (HAART); however, HIV remains a relative contraindication to lung transplantation. We describe, to our knowledge, the first HIV seropositive lung transplant recipient in Canada. We also review the literature of previously reported cases of solid-organ transplantation in patients with HIV with a focus on immunosuppression considerations.

Case presentation: A 48-year old man received a bilateral lung transplant for a diagnosis of desquamative interstitial pneumonia (DIP) attributed to cigarette and cannabis smoking. His control of HIV infection pre-transplant was excellent on HAART, and he had no other contraindications to lung transplantation. The patient underwent bilateral lung transplantation using basiliximab, methylprednisolone, and mycophenolate mofetil (MMF) as induction immunosuppression. He was maintained on MMF, prednisone, and tacrolimus thereafter, and restarted his HAART regimen immediately post-operatively. His post-transplant course was complicated by Grade A1 minimal acute cellular rejection, as well as an enterovirus/rhinovirus graft infection. Despite these complications, his functional status and control of HIV infection remain excellent 24 months post-transplant.

Conclusions: Our patient is one of only several HIV seropositive lung transplant recipients reported globally. With growing acceptance of transplantation in this population, there is a need for clarification of prognosis posttransplantation, as well as optimal immunosuppression regimens for these patients. This case report adds to the recent literature that suggests HIV seropositivity should not be considered a contraindication to lung transplantation, and that post-transplant patients with HIV can be managed safely with basiliximab, tacrolimus, MMF and prednisone.
\end{abstract}

Keywords: HIV, Lung transplant, Desquamative interstitial pneumonia, Immunosuppression

\section{Background}

Until recently, lung transplantation was not considered in patients with human immunodeficiency virus (HIV) given the poor prognosis associated with being HIV seropositive and the need for additional post-transplant immunosuppression. With the advent of highly active

\footnotetext{
*Correspondence: chris.ryerson@hli.ubc.ca

'Lung Transplant Program, Vancouver General Hospital, 2775 Laurel Street, 5th Floor, Vancouver, BC V5Z 1M9, Canada

${ }^{8}$ Centre for Heart Lung Innovation, St. Paul's Hospital, Room 166 - 1081

Burrard Street, Ward 8B, Vancouver, BC V6Z 1Y6, Canada

Full list of author information is available at the end of the article
}

antiretroviral therapies (HAART) for HIV, seropositive patients with suppressed viral loads can now expect long-term survival. Despite these advances, HIV seropositivity remains a relative contraindication to lung transplantation per International Society for Heart and Lung Transplantation (ISHLT) guidelines [1], and there are few reports of HIV seropositive patients who have undergone lung transplantation [2-4].

Here, we describe, to our knowledge, the first HIV seropositive lung transplant recipient in Canada. We also provide a literature review of previously reported

(c) The Author(s). 2018 Open Access This article is distributed under the terms of the Creative Commons Attribution 4.0 International License (http://creativecommons.org/licenses/by/4.0/) which permits unrestricted use, distribution, and reproduction in any medium, provided you give appropriate credit to the original author(s) and the source, provide a link to the Creative Commons license, and indicate if changes were made. The Creative Commons Public Domain Dedication waiver (http://creativecommons.org/publicdomain/zero/1.0/) applies to the data made available in this article, unless otherwise stated. 
cases of solid-organ transplantation in patients with HIV, with a focus on immunosuppression considerations and prognosis.

\section{Case presentation}

A 48-year-old man received a bilateral lung transplant for a diagnosis of desquamative interstitial pneumonia (DIP) that was attributed to smoking cigarettes and cannabis, both of which he ceased 20 months prior to transplantation. The diagnosis of DIP was based on compatible imaging and a prior surgical lung biopsy that was performed at the age of 44 years (Figs. 1 and 2).

The patient was diagnosed with HIV at the age of 38 years and had started HAART 20 months prior to transplantation at age 47. He achieved excellent control of his HIV infection, with a pre-transplant $\mathrm{CD} 4^{+}$cell count of 950 cells $/ \mu \mathrm{L}, \mathrm{CD}^{+}: \mathrm{CD}^{+}$ratio of 0.69 , no detectable viral load, and no history of AIDS-defining illnesses. His HIV was initially managed with cobicistat, elvitegravir, emtricitabine, and tenofovir, which were subsequently changed to abacavir, dolutegravir, and lamivudine when lung transplantation became a consideration due to pharmacokinetic interactions between cobicistat and tacrolimus [5-8].

The patient had progressively worsening dyspnea and lung function that prompted initiation of long-term prednisone and eventually mycophenolate mofetil (MMF), which were both prescribed in consultation with his HIV specialist. His interstitial lung disease continued to progress both clinically and radiographically (Fig. 1), with pre-transplant lung function showing a forced expiratory volume in $1 \mathrm{~s}\left(\mathrm{FEV}_{1}\right) 55 \%$ predicted, forced vital capacity (FVC) $50 \%$ predicted, and diffusing capacity for carbon monoxide (DLCO) 36\% predicted. Prior to transplant, he required 21 oxygen via nasal prongs at rest.

His induction immunosuppression included basiliximab (20 $\mathrm{mg}$ on date of transplantation and post-operative day 4), methylprednisolone (500 $\mathrm{mg}$ at induction, $500 \mathrm{mg}$ at reperfusion, and three doses of $125 \mathrm{mg}$ on the day of transplant), and MMF (1 g pre-transplant). His explanted lungs still showed a pattern of DIP, but with a decreased number of airspace macrophages and a picture that in areas was more consistent with fibrotic nonspecific interstitial pneumonia (NSIP) (Fig. 3). A similar progression of DIP to an NSIP-like picture has been reported previously [9].

Post-transplant, his maintenance immunosuppression included MMF $1 \mathrm{~g}$ twice daily, prednisone $15 \mathrm{mg}$ daily, and tacrolimus, dosed to a target trough level of 10-12 ng/mL. His previous HAART regimen was also continued. The patient had an uncomplicated course in hospital and was discharged from the intensive care unit on post-operative day 3 and discharged from hospital on day 18. He was maintained on daily valganciclovir $900 \mathrm{mg}$, trimethoprim-sulfamethoxazole $160-800 \mathrm{mg}$, and azithromycin $250 \mathrm{mg}$ for prophylaxis against opportunistic infections. Valganciclovir was discontinued 6 months post-transplant as cytomegalovirus DNA remained undetectable in his serum. His tacrolimus trough levels were reduced to $8-10 \mathrm{ng} / \mathrm{mL} 10$ months post-transplant. His prednisone dose was reduced to $10 \mathrm{mg}$ and then subsequently $5 \mathrm{mg}$ daily at 6 - and 14-months post-transplant respectively.

He had an episode of Grade A1 minimal acute cellular rejection detected on surveillance transbronchial biopsy 3 months post-transplant. This was not treated, and there was no evidence of graft rejection on repeat biopsies 1 month later. He had an enterovirus/rhinovirus graft infection with significant allograft dysfunction 11 months post-transplant and received 3 daily doses of methylprednisolone $500 \mathrm{mg}$ with a following prednisone dose of $60 \mathrm{mg}$ daily, tapered by $5 \mathrm{mg}$ every 5 days to a baseline dose of $10 \mathrm{mg}$ thereafter. At the time of this infection, he also received a single dose of intravenous immunoglobulin $0.5 \mathrm{~g} / \mathrm{kg}$.

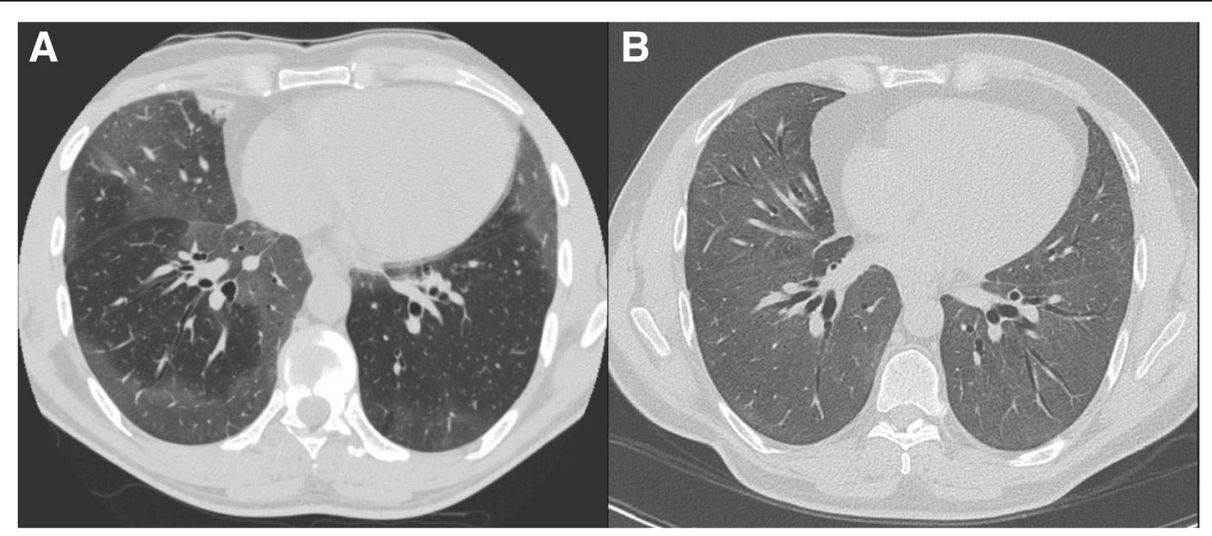

Fig. 1 High-resolution computed tomography (HRCT) of the chest in axial cut from time of initial presentation (a), and 2 years post-diagnosis (b). Both HRCTs demonstrate multifocal ground glass consolidation, primarily in the lower lung zones, progressive over an 8-year period 


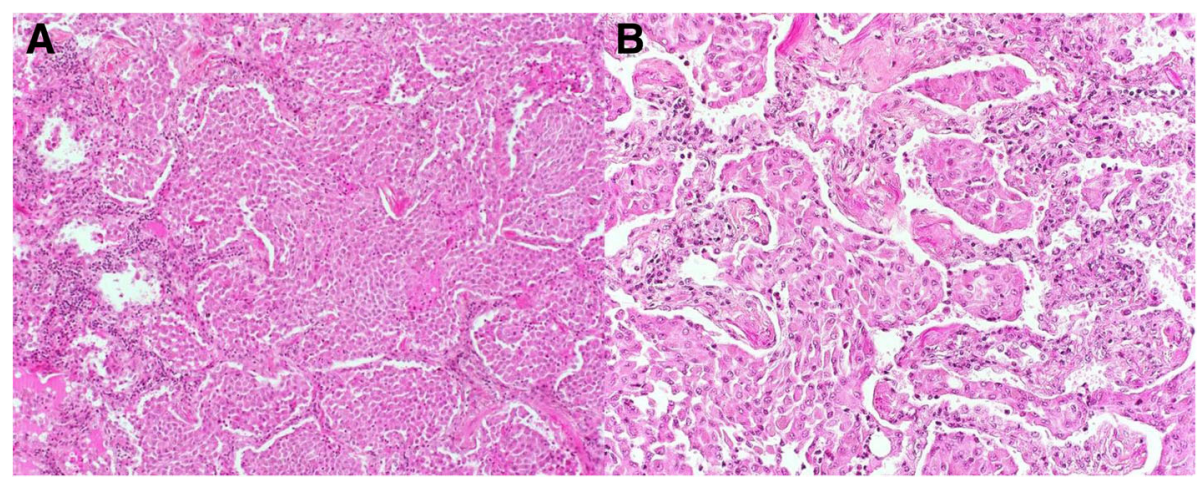

Fig. 2 Haematoxylin phyloxin saffron stain at 100x (a), and 200x (b) of surgical lung biopsy specimen showing filling of alveolar spaces by macrophages. There is mild interstitial inflammatory infiltrate

Post-transplant, the patient's markers of HIV infection continue to be controlled, with $\mathrm{CD} 4^{+}$cell count nadir of 120 cells $/ \mu \mathrm{L}$ on post-operative day $3 . \mathrm{CD}^{+}$count increased to 630 cells/ $\mu \mathrm{L}$ at time of discharge from hospital, and was 940 cells $/ \mu \mathrm{L}$ at 24 months post-transplant, with a $\mathrm{CD}^{+}: \mathrm{CD}^{+}$ratio of 1.03 , and undetectable viral load throughout (Fig. 4). He continues to have normal functional status, no dyspnea, normal lung function, and normal ambulatory oxygenation 24 months post-transplantation.

\section{Discussion and conclusions}

There have been eight previously reported cases of lung transplantation in HIV seropositive patients globally [2-4]. Of the 5 patients who received transplantation more than 3 years ago, 4 have achieved 3-year survival, which is a comparable outcome to non-HIV seropositive patients $[4,10]$. There are also numerous reports of HIV seropositive patients who have received heart transplants, the majority of which have had good outcomes since the introduction of HAART [11]. Observational data from renal and liver transplant populations have generally suggested that HIV seropositive patients have similar survival compared to seronegative patients if maintained on HAART [12-15]. Conversely, the largest cohort study of HIV seropositive liver and kidney recipients to date reported an increased risk of graft failure in recipients from both subpopulations [16], and a higher risk of mortality in liver recipients. Multiple other studies have also suggested a higher than expected risk of acute rejection in HIV seropositive kidney recipients $[13,15,17,18]$.

Until recently, induction immunosuppression was thought to increase the risks of adverse outcomes in HIV seropositive patients [19]. Modern immunosuppression regimens for induction and acute rejection in solid-organ transplant recipients rely on the inhibition of lymphocyte proliferation and activity, and occasionally the more widespread reduction of lymphocyte populations. This latter approach presents unique challenges in HIV seropositive transplant recipients given $\mathrm{CD}^{+}$cell populations and $\mathrm{CD} 4^{+}: \mathrm{CD}^{+}$ratios are important prognostic factors in the management of HIV progression and treatment response [20-22]. This applies to both medications frequently used in the induction and maintenance phases of post-lung transplantation immunosuppression.

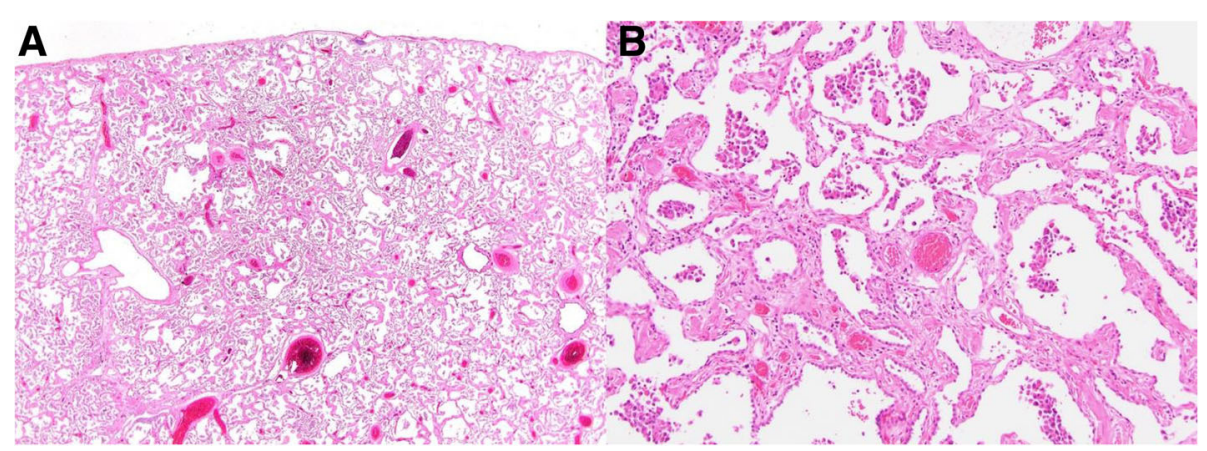

Fig. $310 \times$ (a) and 100x (b) views of the explanted lungs. The number of airspace macrophages has considerably decreased compared to the surgical lung biopsy, and the process more closely resembles fibrotic non-specific interstitial pneumonia than desquamative interstitial pneumonia 


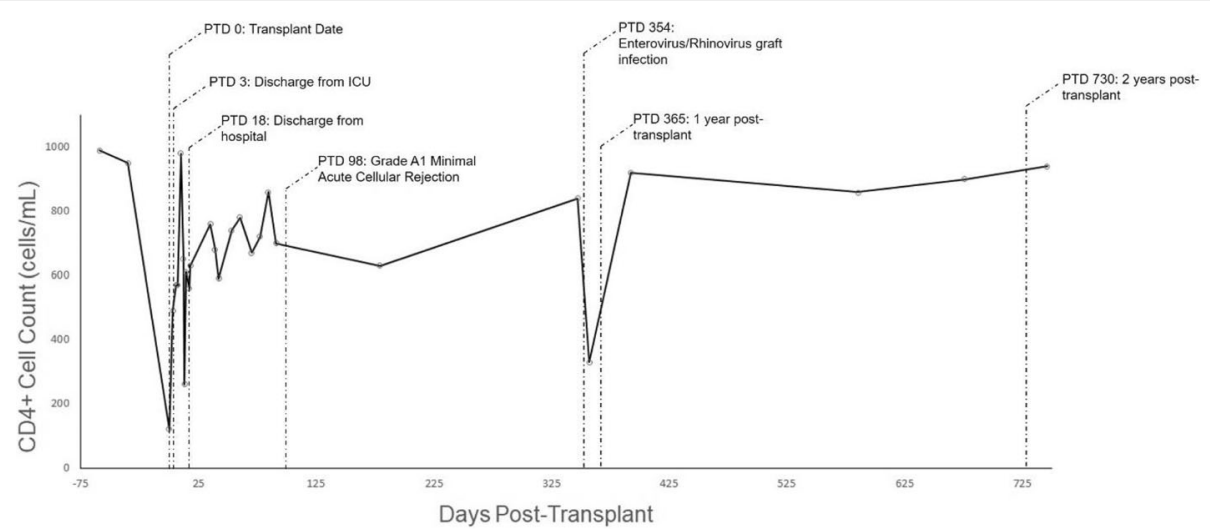

Fig. $4 \mathrm{CD}^{+}$cell count in relation to date of bilateral lung transplant. Significant events during the patient's course are denoted by annotations with post-transplant day (PTD) specified

Induction therapies for lung transplant typically include anti-thymocyte globulin (ATG) and basiliximab. ATG is a polyclonal antibody that actively depletes T-lymphocytes. ATG reduces $\mathrm{CD}^{+}$cell counts immediately after treatment, and also causes prolonged suppression of $\mathrm{CD}^{+}: \mathrm{CD}^{+}$ratios $[23-25]$. When used as induction immunosuppression in lung transplantation, ATG may increase overall survival by reducing graft loss despite also increasing the risk of infection [26]. In the largest cohort of HIV seropositive liver and kidney transplant recipients to date, ATG use in the first week post-kidney transplantation was associated with increased mortality and graft loss $[13,16]$. Other studies in HIV seropositive renal transplant recipients have instead suggested that induction immunosuppression with ATG does not increase the risk of infection compared to HIV seronegative controls, and furthermore decreases the risk of graft loss and increases survival [19,27]. Basiliximab is an IL-2 receptor antagonist that inhibits proliferation and differentiation of T-cells. IL-2 receptor antagonists continue to be the most frequently used induction agents in HIV seronegative lung transplant recipients [28]. Basiliximab use in induction for HIV seropositive renal transplant recipients has been associated with a lower incidence of delayed graft function, reduced graft loss, and a trend towards longer survival compared to no induction [19]. These findings therefore support the use of basiliximab in the induction phase for HIV seropositive lung and renal transplant recipients. Basiliximab may be a preferable induction agent for HIV seropositive patients given ATG's adverse effects on $\mathrm{CD} 4^{+}$cell populations and its association with increased mortality and graft loss in HIV seropositive renal transplant populations. Our patient tolerated the use of basiliximab as induction therapy well, and had no major adverse events and long-term sequelae attributed to its use.
Maintenance immunosuppressive therapies post-lung transplantation in most centers typically include tacrolimus, MMF, and prednisone, which all exert cytostatic effects on T-cell populations via several mechanisms [29-35]. MMF also exerts apoptotic effects on $\mathrm{CD}^{+}$cells in vitro [36]. Despite these findings, neither HIV seropositive or seronegative patients treated with these medications exhibit sustained decreases in their absolute $\mathrm{CD} 4^{+}$cell counts or declines in their $\mathrm{CD}^{+}: \mathrm{CD}^{+}$ratios $[13,18,25,36-40]$. Cobicistat and the protease inhibitor medications increase plasma calcineurin inhibitor levels via cytochrome P450 3A and P-glycoprotein inhibition [5-8], necessitating close monitoring of drug levels when these medications are co-administered with tacrolimus. These interactions were avoided in our patient with alterations to his HAART. Based on this information, HIV seropositive lung transplant recipients can safely be managed with MMF and tacrolimus. Our patient received these medications, as well as prednisone, and had no long-term complications with respect to graft rejection or control of HIV over a 2-year period, which further suggests that HIV seropositive patients can tolerate this immunosuppressant regimen if their HAART is carefully tailored.

In summary, this is the first HIV seropositive lung transplant recipient in Canada to our knowledge, and one of only several patients reported globally. Our immunosuppression selection included basiliximab, corticosteroids, tacrolimus and MMF; a regimen that is supported by evidence drawn from kidney and liver transplant populations. This case report adds to the growing body of literature that these medications are safe in HIV seropositive patients undergoing lung transplantation, and that these patients can achieve long-term outcomes that are comparable to HIV seronegative patients. There is, however, a need for large-scale 
studies of this specific population given the lack of evidence in optimal immunosuppression for these patients, as well as their long-term prognosis. This is especially the case with future trends towards increasing acceptance of solid-organ transplantation in selected HIV seropositive patients.

\section{Abbreviations}

ATG: Anti-thymocyte globulin; DIP: Desquamative interstitial pneumonia; DLCO: Diffusing capacity for carbon monoxide; FEV1: Forced expiratory volume in $1 \mathrm{~s}$; FVC: Forced vital capacity; HAART: Highly active antiretroviral therapy; HIV: Human immunodeficiency virus; ISHLT: International Society for Heart and Lung Transplantation; MMF: Mycophenolate mofetil;

NSIP: Nonspecific interstitial pneumonia

\section{Author's contributions}

The first draft of the manuscript was produced by SO, RDL, and CJR. All authors reviewed, edited, and approved the final version of the submitted manuscript.

\section{Ethics approval and consent to participate}

Not applicable.

\section{Consent for publication}

This case report details information regarding a human patient, and was reported with the express written consent of this patient.

\section{Competing interests}

The authors declare that they have no competing interests.

\section{Publisher's Note}

Springer Nature remains neutral with regard to jurisdictional claims in published maps and institutional affiliations.

\begin{abstract}
Author details
'Department of Medicine, University of British Columbia, 2775 Laurel Street, 10th Floor, Vancouver, BC V5Z 1M9, Canada. ${ }^{2}$ Lung Transplant Program, Vancouver General Hospital, 2775 Laurel Street, 5th Floor, Vancouver, BC V5Z $1 \mathrm{M} 9$, Canada. ${ }^{3}$ Division of Respirology, Department of Medicine, University of British Columbia, 2775 Laurel Street, 7th Floor, Vancouver, BC V5Z 1M9, Canada. ${ }^{4}$ Division of Thoracic Surgery, Department of Surgery, University of British Columbia, 950 West 10th Avenue, Vancouver, BC V5Z 1M9, Canada. ${ }^{5}$ Department of Pharmacology, University of British Columbia, 217 - 2176 Health Sciences Mall, Vancouver, BC V6T 1Z3, Canada. ${ }^{6}$ Vancouver Coastal Health Research Institute, University of British Columbia, 2635 Laurel Street, Vancouver, BC V5Z 1M9, Canada. 'Department of Pathology, University of British Columbia, Room G227 - 2211 Wesbrook Mall, Vancouver, BC V6T 2B5, Canada. ${ }^{8}$ Centre for Heart Lung Innovation, St. Paul's Hospital, Room 166 1081 Burrard Street, Ward 8B, Vancouver, BC V6Z 1Y6, Canada. 'Department of Pathology, Centre Hospitalier de l'Université de Montréal, University of Montreal, 1051 Sanguinet Street, Montreal, QC H2X 3E4, Canada. ${ }^{10}$ Department of Radiology, Centre Hospitalier de I'Université de Montréal, University of Montreal, 1051 Sanguinet Street, Montreal, QC H2X 3E4, Canada. ${ }^{11}$ Division of Infectious Diseases, Department of Medicine, University of British Columbia, 452D - 2733 Heather Street, Vancouver, BC V5Z 3J5, Canada. ${ }^{12}$ Division of Respirology, Department of Medicine, Centre Hospitalier de l'Université de Montréal, 1051 Sanguinet Street, Montreal, QC H2X 3E4, Canada.
\end{abstract}

Received: 1 June 2018 Accepted: 2 October 2018

Published online: 16 October 2018

\section{References}

1. Weill D, Benden C, Corris PA, Dark JH, Davis RD, Keshavjee S, et al. A consensus document for the selection of lung transplant candidates: 2014-an update from the pulmonary transplantation Council of the International Society for heart and lung transplantation. J Heart Lung Transplant. 2015;34(1):1-15.
2. Bertani A, Grossi P, Vitulo P, DAncona G, Arcadipane A, Costa AN, et al. Successful lung transplantation in an HIV- and HBV-positive patient with cystic fibrosis. Am J Transplant. 2009;9(9):2190-6.

3. Kern RM, Seethamraju H, Blanc PD, Sinha N, Loebe M, Golden J, et al. The feasibility of lung transplantation in HIV-seropositive patients. Ann Am Thoracic Soc. 2014;11(6):882

4. Koval C, Malinis M, Mueller N, Krisl J, Hannan M, Grossi P, et al. Heart and lung transplantation outcomes in HIV-positive recipients. HOBOKEN: WILEY; 2018.

5. Sheikh AM, Wolf DC, Lebovics E, Goldberg R, Horowitz HW. Concomitant human immunodeficiency virus protease inhibitor therapy markedly reduces tacrolimus metabolism and increases blood levels. Transplantation. 1999;68(2):307-9.

6. Barau C, Blouin P, Creput C, Taburet AM, Durrbach A, Furlan V. Effect of coadministered HIV-protease inhibitors on tacrolimus and sirolimus blood concentrations in a kidney transplant recipients. Fundam Clin Pharmacol. 2009;23(4):423-5.

7. Jain AKB, Venkataramanan R, Shapiro R, Scantlebury VP, Potdar S, Bonham $C A$, et al. The interaction between antiretroviral agents and tacrolimus in liver and kidney transplant patients. Liver Transpl. 2002;8(9):841-5.

8. Han Z, Kane BM, Petty LA, Josephson MA, Sutor J, Pursell KJ. Cobicistat significantly increases tacrolimus serum concentrations in a renal transplant recipient with human immunodeficiency virus infection. Pharmacother J Hum Pharmacol Drug Ther. 2016;36(6):e53.

9. Tazelaar HD, Wright JL, Churg A. Desquamative interstitial pneumonia. Histopathology. 2011;58(4):509-16.

10. Lund LH, Khush KK, Cherikh WS, Goldfarb S, Kucheryavaya AY, Levvey BJ, et al. The registry of the International Society for Heart and Lung Transplantation: thirty-fourth adult heart transplantation report-2017; focus theme: allograft ischemic time. J Heart Lung Transplant. 2017;36(10):1037-46.

11. Agüero F, Castel MA, Cocchi S, Moreno A, Mestres CA, Cervera C, et al. An update on heart transplantation in human immunodeficiency virus-infected patients: heart transplantation in HIV-infected patients. Am J Transplant. 2016;16(1):21-8.

12. Qiu JX, Terasaki PI, Waki K, Cai JC, Gjertson DW. HIV-positive renal recipients can achieve survival rates similar to those of HIV-negative patients. Transplantation. 2006;81(12):1658-61.

13. Stock PG, Barin B, Murphy B, Hanto D, Diego JM, Light J, et al. Outcomes of kidney transplantation in HIV-infected recipients. N Engl J Med. 2010; 363(21):2004-14.

14. Cooper C, Kanters S, Klein M, Chaudhury P, Marotta P, Wong P, et al. Liver transplant outcomes in HIV-infected patients: a systematic review and metaanalysis with synthetic cohort. AIDS. 2011;25(6):777-86.

15. Roland ME, Barin B, Carlson L, Frassetto LA, Terrault NA, Hirose R, et al. HIV-infected liver and kidney transplant recipients: 1- and 3-year outcomes. Am J Transplant. 2008;8(2):355-65.

16. Roland ME, Barin B, Huprikar S, Murphy B, Hanto DW, Blumberg E, et al. Survival in HIV-positive transplant recipients compared with transplant candidates and with HIV-negative controls. AIDS. 2016;30(3):435-44.

17. Tan HP, Kaczorowski DJ, Basu A, Khan A, McCauley J, Marcos A, et al. Living-related donor renal transplantation in HIV plus recipients using alemtuzumab preconditioning and steroid-free tacrolimus monotherapy: a single center preliminary experience. Transplantation. 2004;78(11):1683-8.

18. Mazuecos A, Fernandez A, Zarraga S, Andres A, Rodriguez-Benot A, Jimenez $C$, et al. High incidence of delayed graft function in HIV-infected kidney transplant recipients. Transplant Int. 2013;26(9):893-902.

19. Kucirka LM, Durand CM, Bae S, Avery RK, Locke JE, Orandi BJ, et al. Induction immunosuppression and clinical outcomes in kidney transplant recipients infected with human immunodeficiency virus. Am J Transplant. 2016;16(8):2368-76.

20. Choi S, et al. CD4 lymphocytes are an incomplete surrogate marker for clinical progression in persons with asymptomatic HIV infection taking zidovudine. Ann Intern Med. 1993;118(9):674-80.

21. Serrano-Villar S, Moreno S, Fuentes-Ferrer M, Sánchez-Marcos C, Ávila M, Sainz T, et al. The CD4:CD8 ratio is associated with markers of ageassociated disease in virally suppressed HIV-infected patients with immunological recovery. HIV Medicine. 2014;15(1):40-9.

22. Serrano-Villar S, Gutiérrez C, Vallejo A, Hernández-Novoa B, Díaz L, Abad Fernández M, et al. The CD4/CD8 ratio in HIV-infected subjects is independently associated with T-cell activation despite long-term viral suppression. J Infect 2013. 2012;66(1):57-66.

23. Müller TF, Grebe SO, Neumann MC, Heymanns J, Radsak K, Sprenger H, et al. Persistent long-term changes in lymphocyte subsets induced by polyclonal antibodies. Transplantation. 1997;64(10):1432. 
24. Carter JT, Melcher ML, Carlson LL, Roland ME, Stock PG. Thymoglobulinassociated Cd4 T-cell depletion and infection risk in HIV-infected renal transplant recipients. Am J Transplant. 2006;6(4):753-60.

25. Stock PG, Roland ME, Carlson L, Freise CE, Roberts JP, Hirose R, et al. Kidney and liver transplantation in human immunodeficiency virus-infected patients: a pilot safety and efficacy study. Transplantation. 2003;76(2):370-5.

26. Hachem RR, Edwards LB, Yusen RD, Chakinala MM, Alexander Patterson G, Trulock EP. The impact of induction on survival after lung transplantation: an analysis of the International Society for Heart and Lung Transplantation registry. Clin Transpl. 2008;22(5):603-8.

27. Locke JE, James NT, Mannon RB, Mehta SG, Pappas PG, Baddley JW, et al. Immunosuppression regimen and the risk of acute rejection in HIV-infected kidney transplant recipients. Transplant J. 2014;97(4):446-50.

28. Van Raemdonck D, Hartwig MG, Hertz MI, Davis RD, Cypel M, Hayes D, et al. Report of the ISHLT working group on primary lung graft dysfunction part IV: prevention and treatment: a 2016 consensus group statement of the International Society for Heart and Lung Transplantation. J Heart Lung Transplant. 2017;36(10):1121-36.

29. Allison AC, Eugui EM. Mycophenolate mofetil and its mechanisms of action. Immunopharmacology. 2000;47(2-3):85-118.

30. Allison AC, Eugui EM. Immunosuppressive and other effects of mycophenolic-acid and an ester prodrug, mycophenolate mofetil. Immunol Rev. 1993;136(1):5-28.

31. Eugui EM, Allison AC. Immunosuppressive activity of mycophenolate mofetil. Ann N Y Acad Sci. 1993;685(1 Immunomodulat):309-29.

32. Ho S, Clipstone N, Timmermann L, Northrop J, Graef I, Fiorentino D, et al. The mechanism of action of Cyclosporin a and FK506. Clin Immunol Immunopathol. 1996;80(3):S45.

33. Kiani A, Rao A, Aramburu J. Manipulating immune responses with immunosuppressive agents that target NFAT. Immunity. 2000;12(4):359-72.

34. Granellipiperno A, Nolan P, Inaba K, Steinman RM. The effect of immunosuppressive agents on the induction of nuclear factors that bind to sites on the interleukin-2 promoter. J Exp Med. 1990;172(6):1869-72.

35. Tocci MJ, Matkovich DA, Collier KA, Kwok P, Dumont F, Lin S, et al. The immunosuppressant FK506 selectively inhibits expression of early $T$ cell activation genes. J Immunol. 1989;143(2):718-26.

36. Pantaleo G, Paolo Rizzardi G, Chapuis AG, Acha-Orbea H, Attinger A, Fleury $S$, et al. Effects of mycophenolic acid on human immunodeficiency virus infection in vitro and in vivo. Nat Med. 2000;6(7):762-8.

37. Press N, Kimel G, Harris M, Yip B, Craib KJP, Montaner JSG. Case series assessing the safety of mycophenolate as part of multidrug rescue treatment regimens. HIV clinical trials. 2002;3(1):17-20.

38. Gómez V, Fernández A, Galeano C, Oliva J, Diez V, Bueno C, et al. Renal transplantation in HIV-infected patients: experience at a tertiary Hospital in Spain and Review of the literature. Transplant Proc. 2013;45(3):1255-9.

39. Bravo Soto JA, de la Rosa RE, del Castillo JL, Morales SC, Olivares EG, Ortega $\mathrm{AO}$, et al. Effect of mycophenolate mofetil regimen on peripheral blood lymphocyte subsets in kidney transplant recipients. Transplant Proc. 2003; 35(4):1355-9.

40. Sankatsing SUC, Jurriaans S, van Swieten P, van Leth F, Cornelissen M, Miedema F, et al. Highly active antiretroviral therapy with or without mycophenolate mofetil in treatment-naive HIV-1 patients. AIDS. 2004;18(14):1925-31.

Ready to submit your research? Choose BMC and benefit from:

- fast, convenient online submission

- thorough peer review by experienced researchers in your field

- rapid publication on acceptance

- support for research data, including large and complex data types

- gold Open Access which fosters wider collaboration and increased citations

- maximum visibility for your research: over $100 \mathrm{M}$ website views per year

At $\mathrm{BMC}$, research is always in progress.

Learn more biomedcentral.com/submissions 